\title{
10
}

\section{The impact of the guest-worker system on poverty and the well-being of migrant workers in urban China}

\section{Yang Du, Robert Gregory and Xin Meng}

Many countries adopt a guest-worker system to help meet labour shortages. Guest workers normally have a temporary visa to work in the host country but have no political rights or access to social welfare and other government-provided benefits. Under such a system, guest workers normally spend some part of their working life in the host country and return home when their work or family circumstances change. Their usual objective is to make and save as much money as they can before they return home.

China is, perhaps, the only country in the world that adopts a guest-worker system for its own rural citizens (Roberts 1997; Solinger 1999; Meng 2000). There are currently more than 120 million rural-to-urban migrants working in Chinese cities and they have contributed substantially to the country's recent unprecedented economic growth. Nevertheless, like all guest workers, they have temporary work visas and no access to the social benefits that are available to their urban counterparts. There are no safety nets, no adequate access to health facilities and their children do not have equal access to schooling.

Migrants often earn lower incomes than natives, especially in the initial stage of migration. This is due partly to lack of knowledge of local labour markets and partly to lack of local labour market-specific human capital (see, for example, Chiswick 1978 and Borjas 1985, 1995). Lower incomes are also due partly to employer (or government) discrimination. In China, discrimination against rural migrants is usually institutionalised, whereby city governments prevent rural migrants from obtaining higher-paying jobs, which are reserved for urban citizens 
(Zhao 2003; Meng and Zhang 2001). Studies have continuously found that migrants often possess low-paying and 'three-D' jobs (disgraceful, dirty and dangerous) and that their earnings are much lower than their urban counterparts (Meng 2000; Meng and Zhang 2001; Zhao 2002; and Fang et al. 2003).

Under such circumstances, questions naturally arise as to the kind of lives migrants are living in cities and how their short-term objective of making and saving as much money as possible might affect their lives in the future.

The answers to these questions have important political and policy implications. First, migrant workers currently account for one-third of the Chinese urban labour force. In the next 10 to 20 years, this figure is predicted to double. If many migrant workers are living in poverty, and are concentrated in ghettos, conditions of crowding and poverty might lead to high crime rates and social and political instability.

Second, China's current urban social safety net is accessible only to urban residents. This situation, however, is not sustainable. As the Chinese economy grows and more and more rural migrants come to the cities, a coherent social safety net that covers urban residents and rural migrants will need to be established. Understanding the extent to which migrant workers currently live in poverty is a crucial piece of information to be used in designing an appropriate system and projecting its possible cost.

Third, even if migrant workers and their families are not currently living in poverty, the short-term objectives of making and saving as much money as they can by working exceptionally long hours might place them in an environment in which, in the near future, their health and hence their earning capacity might deteriorate. Any future health deterioration will not only adversely affect individual well-being, it will be of considerable social and political importance.

Using two recently available data sources, the China Income Distribution Survey (CIDS) (Chinese Academy of Social Sciences 2002) and the China Urban Labour Survey (CULS) (Chinese Academy of Social Sciences 2001), we examine three specific issues related to poverty and the well-being of rural migrants.

First, what proportion of migrant workers is currently living in poverty, as measured by the application of the usual income and expenditure poverty lines? Second, what is the relationship between these poverty levels and the long hours typically worked by migrants? And, finally, how might the long hours worked and current work and living conditions affect the future health of migrants?

The chapter is structured as follows. The next section provides background on rural-urban migration and describes the data. Section three assesses urban poverty using different poverty lines and examines how the urban poverty rate and poverty severity might change if we include a migrant sample. The fourth section discusses 
how extremely long hours worked by migrants enable them to live just above the poverty line and, had they worked 'normal hours', what proportion of them would have lived below the poverty line. Section five predicts the possible adverse impact of current long working hours on migrants' future health, while conclusions and policy implications are given in the final section.

\section{Background and data}

China's internal rural-urban migration takes place within a guest-worker system, whereby migrant workers are restricted in the type of job they can obtain and in terms of access to urban social services, such as education, health care, unemployment benefits and pensions. These restrictions prevent migrant workers from staying in cities for a long period and from bringing their families to the cities. Thus, migrants often work in the cities for a few months to a few years, depending on their personal and family circumstances, and then go back to their country home. Sometimes, they migrate back and forth.

When farmers migrate, their families are permitted to keep their land. In this way, land is a safety net for migrant workers. If they lose their jobs and are unable to find another job in a short time, they might return to the countryside to work on the farm. Similarly, if they become sick in the cities, they will have no choice but to go back to the countryside. In the countryside, there are relatives who can provide care, and the cost of living is much lower, although health care is much worse in the countryside and health expenditure is not cheap.

Under the guest-worker system, the effect of rural-urban migration on total urban poverty is unclear. On the one hand, as migrant workers can obtain only lowincome jobs, it is possible that a larger proportion of migrants are living in poverty than their urban resident counterparts.

On the other hand, unsuccessful migrants are more likely to go back to the countryside. Those who stay in cities are usually employed and are a relatively successful group. In other words, the guest-worker system might act as a buffer that pushes unemployed and very poor migrants back to the countryside. ${ }^{1}$

In these circumstances, migrants might not contribute to an increase in total urban poverty.

There is another issue. Poverty, measured in terms of current income, might not capture current living conditions and the long-term poverty of migrant workers. This is because migrants do not see their future in the cities. They come to earn and save as much as possible and to take their savings home for their future prosperity. With such an objective in mind, they might sacrifice current living 
conditions for their own and their family's future. They might choose to work extremely hard and live in extremely poor conditions while working in the cities. Such short-term behaviour might damage their long-term health, and hence, hinder their long-term earnings capacity and future wealth.

To study these issues, we employ data from two recent surveys. The first survey is the China Income Distribution Survey (CIDS) 2002, conducted in 12 provinces $^{2}$ by the Institute of Economics at the Chinese Academy of Social Sciences, while the second is the China Urban Labour Survey (CULS) 2001, conducted in five large capital cities (Shanghai, Wuhan, Shenyang, Xian and Fuzhou) by the Institute of Population and Labour Economics at the Chinese Academy of Social Sciences.

Both surveys include samples of urban residents and rural-urban migrants in the same cities or provinces. The CIDS comprises 6,835 households and 20,632 individuals in the urban resident sample and 2,000 households and 5,327 individuals in the migrant sample, while the CULS consists of 3,499 households and 8,109 individuals in the urban resident sample and 2,400 individuals in the migrant sample. ${ }^{3}$

In each survey, the questionnaires were largely comparable for urban residents and rural migrants. Each survey has advantages and disadvantages relative to the other.

The CIDS has a larger sample than the CULS and includes large (37 per cent of the sample individuals), medium and small cities (63 per cent of the sample individuals). The survey has good records of individual income, including every person in the household for urban resident and migrant samples. In addition, there are detailed consumption expenditure data.

The CULS sample includes only five large cities. ${ }^{4}$ The main advantage of the CULS is that it collects urban and migrant work histories and working hours at different stages of working life. One of its shortcomings is that the migrant survey asks questions only about the main respondent of each household. Although information is also gathered regarding age, education, working status, whether working in the same city and the type of job of the respondent's spouse, parents, children and siblings, no earnings information is available for these relatives. It is therefore impossible to derive household per capita income for migrants. Second, many household-level figures, especially expenditure, are not available for migrants due to the individual nature of the survey.

The CULS and CIDS have a large proportion of self-employed migrants (about 51-53 per cent in both samples). Whether this reflects the population occupational distribution is unknown as even the census did not ask questions as to whether a 
migrant was working as a wage or salary earner or was self-employed. Nevertheless, the common belief is that the proportion of self-employed from these surveys is too high. The main reason for this is that workers who live on construction sites and in factory dormitories do not normally register with the urban community authorities. ${ }^{5}$

To help offset any bias in the samples, the analyses below present results for total migrant samples and a sample of migrant wage and salary earners only. Table 10.1 presents summary statistics. ${ }^{6}$ Many interesting facts are revealed from this table. First, on average, migrants are about 12-23 years younger and have about two to three years less education than their urban counterparts.

Second, the proportion of household members who are employed differs greatly between urban residents and migrants. About $70-86$ per cent of migrants in cities are working, while this ratio for urban residents is between 40 and 50 per cent, suggesting that, as guest workers, migrants leave their non-working family members back in the rural villages.

Third, rural migrants earn less, spend less and save more than urban residents. On average, based on the CIDS, migrant earnings per worker are 9,142 yuan per annum and per capita income is 6,486 yuan, while these figures for urban residents are 12,162 yuan and 8,246 yuan, respectively. Urban residents earn 33 and 27 per cent more than their migrant counterparts.

Migrant savings, however, are higher than urban residents. On average, migrants save 2,214 yuan per capita per annum-34 per cent of their per capita income while the average saving rate for urban residents is 24 per cent. The low income and high saving rates indicate that migrants live in much harsher conditions than their urban counterparts. This can be shown from their housing conditions. Per capita living area for migrants is about 11 square metres, while for urban residents it is 19-23 sq m. About 63 per cent of migrant households do not have a bathroom, while for urban residents it is 16 per cent.

Fourth, migrants have limited access to social benefits. For example, while 65 per cent of urban employed individuals are eligible for public health insurance, this ratio is 4 per cent for migrants. Despite this, migrants spend less on health. While per capita health expenditure is about 450 yuan annually for urban residents, the figure for migrant households is 243 yuan, almost half that for the urban residents. Obviously, saving motivations contribute to the low health expenditure of migrant workers. As medical expenditure is very high in many cities, ${ }^{7}$ when health problems arise migrants often try to avoid seeing doctors.

As Xiang (2003) indicated, on falling ill, migrants would typically wait, hoping the illness would go away. If the situation got worse, they would go to small 


\section{Table 10.1 Summary statistics}

\begin{tabular}{|c|c|c|c|c|}
\hline \multirow[b]{2}{*}{ Households } & \multicolumn{2}{|c|}{ CIDS } & \multicolumn{2}{|c|}{ CULS } \\
\hline & Urban & Migrants & Urban & Migrants \\
\hline Age of the household head & 48.00 & 36.00 & 53.00 & 30.00 \\
\hline Age of employed & 41.00 & 35.00 & 41.00 & 31.00 \\
\hline \multicolumn{5}{|l|}{ Percentage of household heads } \\
\hline are males & 0.67 & 0.80 & 0.71 & 0.61 \\
\hline Years of schooling of household he & ead 10.70 & 8.10 & 10.10 & 8.10 \\
\hline Years of schooling of spouse & 10.20 & $7.20^{\mathrm{a}}$ & 9.00 & 7.90 \\
\hline Household size & 2.99 & 2.69 & 2.89 & 1.82 \\
\hline Percentage of household aged 0 & 0.02 & 0.06 & 0.00 & 0.03 \\
\hline \multicolumn{5}{|l|}{ Percentage of household aged } \\
\hline above 65 & 0.07 & 0.01 & 0.16 & 0.00 \\
\hline Number of employed in household & 1.49 & 1.72 & 1.16 & 1.41 \\
\hline \multicolumn{5}{|l|}{ Percentage of household members } \\
\hline $\begin{array}{l}\text { employed } \\
\text { Percentage of total employed }\end{array}$ & 0.50 & 0.70 & 0.39 & 0.86 \\
\hline who are self-employed & 0.05 & 0.51 & 0.10 & 0.54 \\
\hline Employed annual earnings & $12,162.00$ & $9,142.00$ & $13,900.00$ & $11,158.00^{b}$ \\
\hline Employed monthly hours worked & 191.00 & 291.00 & 195.00 & 306.00 \\
\hline Employed hourly earnings & 5.74 & 3.01 & .. &.. \\
\hline $\begin{array}{l}\text { Percentage employed who are } \\
\text { eligible for health benefits }\end{array}$ & 0.65 & 0.04 & 0.67 & .. \\
\hline \multicolumn{5}{|l|}{ Percentage employed who } \\
\hline $\begin{array}{l}\text { are eligible for housing benefits } \\
\text { Percentage employed }\end{array}$ & .. & 0.06 & 0.47 & .. \\
\hline who are white-collar workers & 0.52 & 0.06 & .. & .. \\
\hline \multicolumn{5}{|l|}{ Percentage employed } \\
\hline Per capita income & $8,246.00$ & $6,486.00$ & $8,690.00$ &.. \\
\hline Per capita total expenditure & $6,294.00$ & $4,272.00$ & $6,224.00$ &.. \\
\hline Per capita savings & $1,952.00$ & $2,214.00$ & $2,466.00$ &.. \\
\hline Saving rate & 0.24 & 0.34 & 0.28 &.. \\
\hline Annual remmitances & n.a. & $1,072.00$ & n.a. & 1,337 \\
\hline Per capita living area & 18.82 & $1,1.25$ & 23.24 .00 & 11.58 \\
\hline Per capita expenditure on housing & 643.00 & $1,178.00$ &.. &.. \\
\hline \multicolumn{5}{|c|}{ Percentage of household living in } \\
\hline housing without a bathroom & 0.16 & 0.63 & .. & .. \\
\hline Percentage of expenditure on food & 0.43 & 0.45 & .. & .. \\
\hline Per capita health expenditure & 448.00 & 243.00 & .. & .. \\
\hline Per capita public health expenditure & e 408.00 & n.a. & .. &.. \\
\hline Number of observations (employed & d) $6,781.00$ & $1,947.00$ & $3,458.00$ & $2,262.00$ \\
\hline Number of observations (householc & d) $10,135.00$ & $3,357.00$ & $4,010.00$ & $3,394.00$ \\
\hline
\end{tabular}

Notes: a Only those whose spouse is present in the same city are counted. ${ }^{b}$ Only the main respondents are asked this question, therefore, it is the mean of the main respondents.

Sources: Chinese Academy of Social Sciences, 2002. China Income Distribution Survey (CIDS), Institute of Economics, Chinese Academy of Social Sciences. Chinese Academy of Social Sciences, 2001. China Urban Labour Survey (CULS), Institute of Population and Labour Economics, Chinese Academy of Social Sciences. 
pharmacies to buy medicines according to their own medical knowledge. Only when the illness became unendurable would they visit a doctor, by which time the disease might already have become very serious. ${ }^{8}$

Fifth, migrants, on average, work 52-56 per cent more hours per month than their urban counterparts and rarely have access to benefits that are commonly available to urban residents.

Finally, in both surveys, individuals were asked to rate their health condition against their age group. The ratings ranged from one for excellent to five for very ill. We group four (ill) and five (very ill) into a dummy variable indicating unhealthy and find that migrants, on average, are less likely than their urban counterparts to rate themselves as being unhealthy.

\section{A simple poverty assessment}

In China, there is no official poverty line for each province or city, however, governments in each region publish the income level at which a household can receive the Minimum Living Allowances (the Dibao Line). The Dibao Line reflects local minimum living standards and local government budgetary situations, as the Minimum Living Allowance is paid by local governments. The Dibao Line is, therefore, often lower than other poverty lines.

The more widely used poverty line is often defined as US $\$ 1$ or US $\$ 2$ a day. This line, however, relies heavily on the purchasing power parity exchange rate, which is not available across different regions within China. In this paper, we follow Ravallion (1994), China Urban Poverty Research Group (2003) and Meng et al. (2005) and use 'the cost of basic needs' (CBN) method.

This method defines the poverty line in four steps. The first step is to define the cost of acquiring 'the minimum nutrition requirement' (MNR). The MNR used in this study is 2,100 calories per person per day, which is used commonly in many poverty studies (Ravallion 1994; Prodhan et al. 2001) and is accepted as the MNR by the Chinese Academy of Preventive Medicine (2001).

The second step is to choose a reference group that purchases the MNR. Our reference group is the poorest 20 per cent of households. Third, we measure the cost of acquiring the MNR by the reference group. This is defined as the food poverty line. Finally, we calculate the non-food component of the cost of basic needs (CBN), as humans not only need food to survive, they need other things such as basic clothing and shelter. ${ }^{9}$

Earnings are not reported for non-respondents in the CULS migrant survey, and hence, it is impossible to obtain per capita income for migrant households. As a 
result, the simple poverty assessment presented in this section will not include the CULS sample.

To use the CBN method to calculate a local poverty line for different cities and provinces, we use the Urban Household Income and Expenditure Survey (UHIES) 2002. This survey samples households with urban household registration for every province in the nation (29 provinces before 1990 and 30 after 1990, due to the establishment of the province of Hainan in 1990). ${ }^{10}$

Households are expected to keep a diary of all expenditure (disaggregated for hundreds of product categories) for each day for a full year. Enumerators visit sample households once or twice each month to review the records, assist the household with their questions and collect the household records for data entry in the local Statistical Bureau office (Han et al. 1995; Fang et al. 2002; and Gibson et al. 2003).

The Dibao and poverty lines calculated using the CBN method for the 15 provinces included in the CIDS are presented in Appendix table 10.2. Although the Dibao line is always lower than the upper CBN poverty line, we use both in our poverty calculation and analyses below.

Table 10.2 presents poverty headcount indices, poverty gap and per capita income and expenditure for urban residents and migrants separately and for the total sample combined (including urban residents and migrants). Focusing on the total sample first, the poverty rate measured using the Dibao and CBN lines and measured in terms of income for urban residents is 3.5 and 6 per cent, respectively, while for migrants it is 10.1 and 15.7 per cent respectively. On average, the poverty rate for migrants is more than double that for urban residents. In addition, there is a larger proportion of poor migrant households with high levels of poverty than of urban residents. The average poverty gap for urban residents and migrants is 0.09 and 0.13 , respectively, using the Dibao and CBN lines.

When the poverty rates are measured in terms of expenditure, they double for urban residents and migrants. The proportion of urban households living under the upper CBN poverty line increases to 12.5 per cent, and the proportion of migrant households increases to 32.4 per cent.

Note that including migrants in the sample increases the income-measured poverty rate by 1.4 to 2.1 percentage points, depending on the poverty line used. These results are largely consistent with the Asian Development Report (ADB 2002) estimates of poverty in urban China in 1998, which reported a 50 per cent higher poverty rate for migrants than for urban residents.

In the second and third columns of each panel in Table 10.2, we report the poverty rate for households without any self-employed and for households with at 
The Turning Point in China's Economic Development

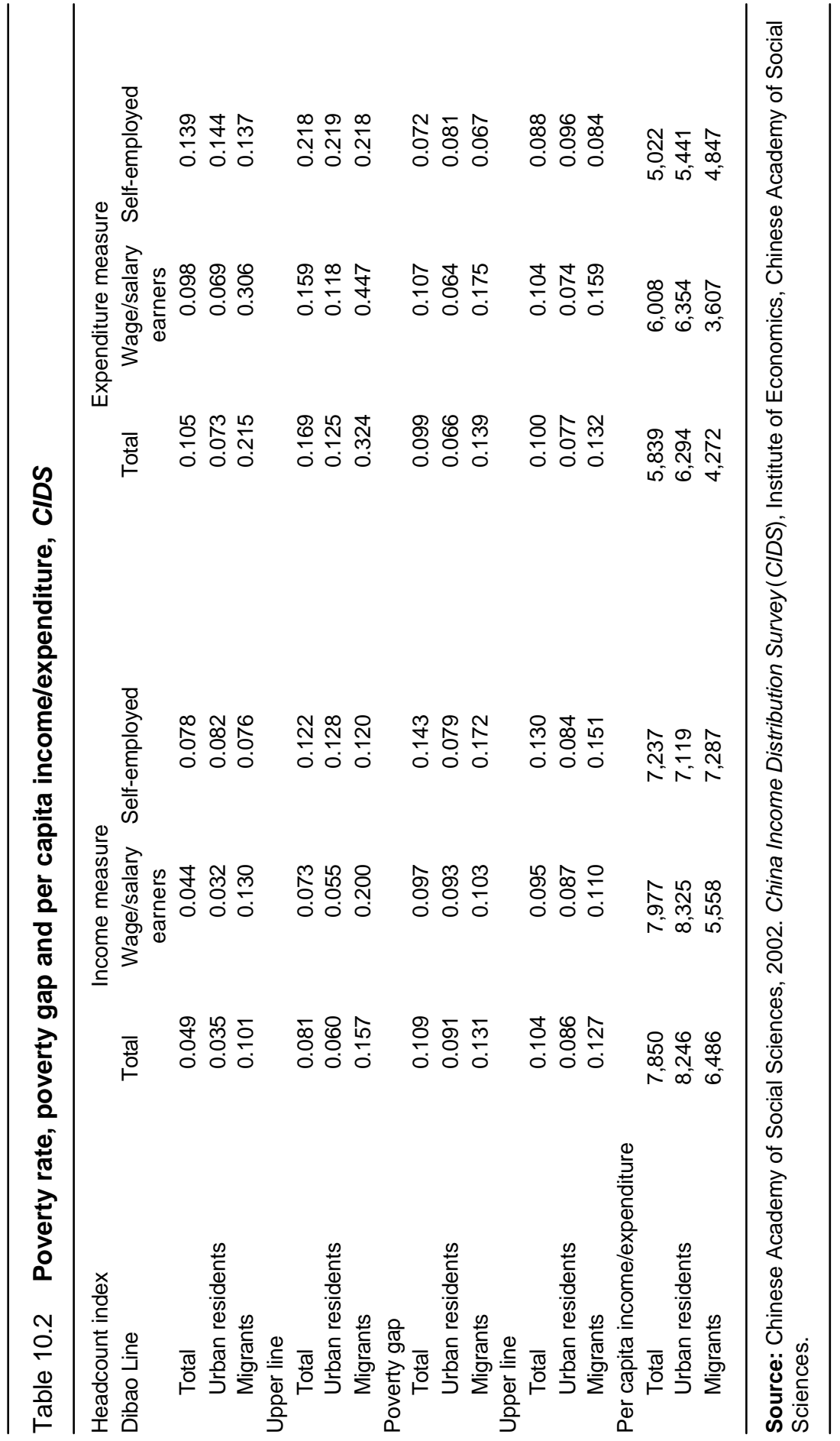


least one member self-employed. The main difference in poverty rates between urban residents and migrants occurs among wage and salary earners, where we observe 20 per cent of migrants with per capita income below the upper CBN poverty line, while the proportion for urban residents is 5.5 per cent.

For the self-employed, there is little difference in poverty rates between urban residents and migrants. If anything, self-employed urban residents are slightly more likely to be living below the poverty line. Note, though, there is only a very small proportion of urban residents who are self-employed (5 per cent in the CIDS; see Table 10.1).

\section{Working your way above the poverty line}

The key issue is why are migrants poor. Is it because they cannot find jobs or is it because hourly earnings are too low? In addition, for those whose incomes are above the poverty line, is this due to their extremely long hours of work?

We first investigate the labour force status of migrants and urban residents (see the first panel of Table 10.3). For individuals aged 16 to 65, about 86 per cent of migrants are working, while this ratio is 64 per cent for urban residents in the CIDS; the ratio is as high as 95 per cent for male migrants and 76 per cent for female migrants. For their urban counterparts, the ratio is 72 and 56 per cent for males and females, respectively. Similar results are found in the CULS. Thus, perhaps, additional migrant poverty is not the result of lower employment rates; it might be because hourly earnings for migrant workers are substantially lower than for their urban counterparts. In other words, they are working poor.

We also examine the average hours worked for workers and for household members aged $16-65$ by migration status, gender (middle panel in Table 10.3) and poverty status (last panel in Table 10.3). We find that on average an employed migrant works about 52 per cent more hours than his/her urban counterpart. In addition, while households living below the poverty line work less hours, this situation is more so for urban residents than for migrants. Migrants who live below the poverty line work 218-274 hours a month, which is almost 51-69 hours a week, while urban residents living below the poverty line work only 13-25 hours a week.

Figures 10.1 and 10.2 present work hours per day, work days per month (per week in the case of the CULS) and hours worked per month for household members aged 16-65. As our migrant sample might include too many self-employed, who normally work longer hours, we present the figures for the total sample and the sample excluding self-employed.

The striking feature of these figures is that the majority of urban workers work a normal eight hours a day and five days a week, but most migrants work more than 


\section{Table 10.3 Working status and working hours of migrants and urban residents}

\begin{tabular}{|c|c|c|c|c|c|c|}
\hline & \multicolumn{3}{|c|}{ CIDS } & \multicolumn{3}{|c|}{ CULS } \\
\hline & Urban & Migrants & $([\mathrm{M} / \mathrm{U}]-1)^{*} 100$ & Urban & Migrants & $([\mathrm{M} / \mathrm{U}]-1)^{*} 100$ \\
\hline \multicolumn{7}{|c|}{ Proportion of those aged $16-65$ working } \\
\hline Total & 63.24 & 85.66 & 35.45 & 59.41 & 91.80 & 54.52 \\
\hline Males & 71.46 & 95.16 & 33.17 & 70.29 & 95.83 & 36.34 \\
\hline emales & 55.35 & 75.64 & 36.66 & 49.41 & 86.59 & 75.25 \\
\hline \multicolumn{7}{|c|}{ Monthly hours worked per employed individual } \\
\hline Total & 192.0 & 291.0 & 51.56 & 195.0 & 306.0 & 56.94 \\
\hline Males & 194.0 & 288.0 & 48.45 & 197.0 & 301.0 & 52.45 \\
\hline Females & 189.0 & 294.0 & 55.56 & 192.0 & 315.0 & 64.09 \\
\hline \multicolumn{7}{|c|}{ Age 16-65 per person monthly hours worked } \\
\hline line & 125.0 & 256.0 & 104.80 & 104.0 & 294.0 & 182.69 \\
\hline \multicolumn{7}{|c|}{ Below poverty } \\
\hline line & 106.0 & 218.0 & 105.66 & 57.0 & 274.0 & 380.70 \\
\hline Total & 124.0 & 250.0 & 101.61 & 100.0 & 293.0 & 193.00 \\
\hline
\end{tabular}

Sources: Chinese Academy of Social Sciences, 2002. China Income Distribution Survey (CIDS), Institute of Economics, Chinese Academy of Social Sciences. Chinese Academy of Social Sciences, 2001. China Urban Labour Survey (CULS), Institute of Population and Labour Economics, Chinese Academy of Social Sciences.

eight hours a day and seven days a week. This is true even when we exclude selfemployed individuals.

It appears that migrant workers spend most of their lives working while they are in the cities. An average of 9.7 hours a day and seven days a week suggests that apart from sleeping (eight hours) and eating (three hours), migrant workers have about only three hours a day left for themselves. Such extremely long hours, combined with high employment rates, should have pushed many above the poverty line.

The issue we are interested in is, if migrants worked similar hours to those worked by urban residents with similar characteristics, how many migrants would have had an income below the poverty line?

If migrants were urban residents, how many hours would they have worked per month?

To answer this question, we estimate the following hours equation

$$
H_{\text {iut }}=W 2_{\text {iut }} \beta+\delta H_{\text {ealth }}{ }_{\text {iut }}+\varepsilon_{\text {iut }}
$$


Figure 10.1 Hours worked per day and days worked per month/week

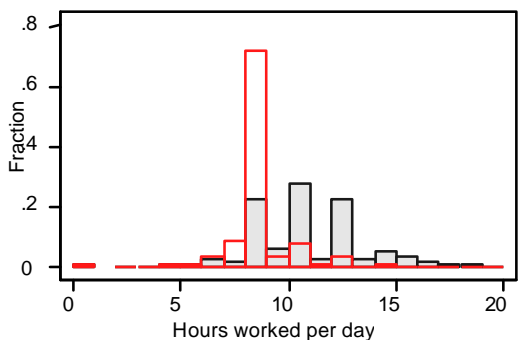

Note: Grey and while bars are for migrants and urban residen ts

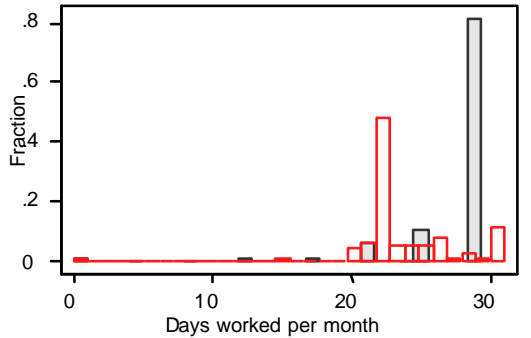

Note: Grey and while bars are for migrants and urban residents



Note: Grey and while bars are for migrants and urban resider ts

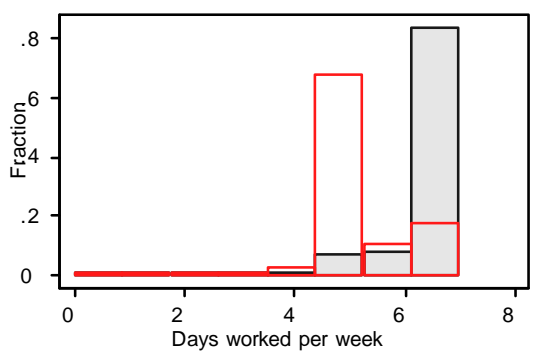

Note: Grey and white bars are for migrants and urban residerts

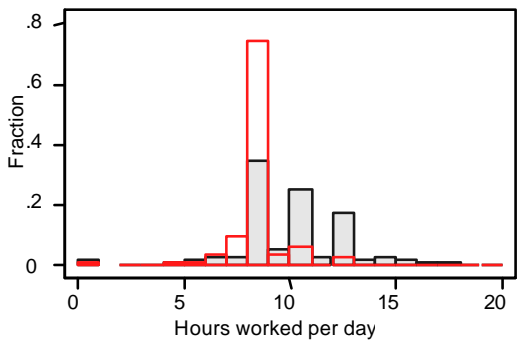

Note: excluding self employed

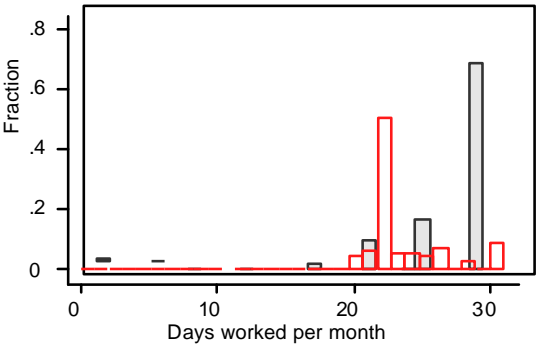

Note: excluding self employed

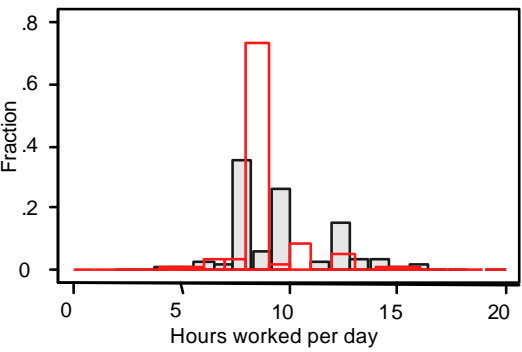

Note: excluding self employed

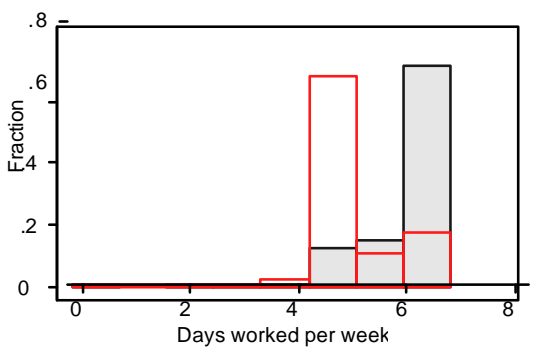

Note: excluding self employed 
Figure 10.2 Hours worked per month
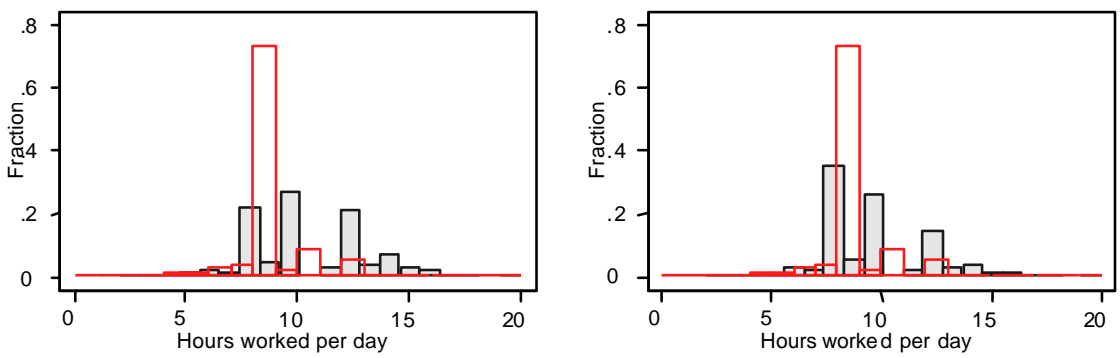

Note: Grey and while bars are for migrants and urban residenits
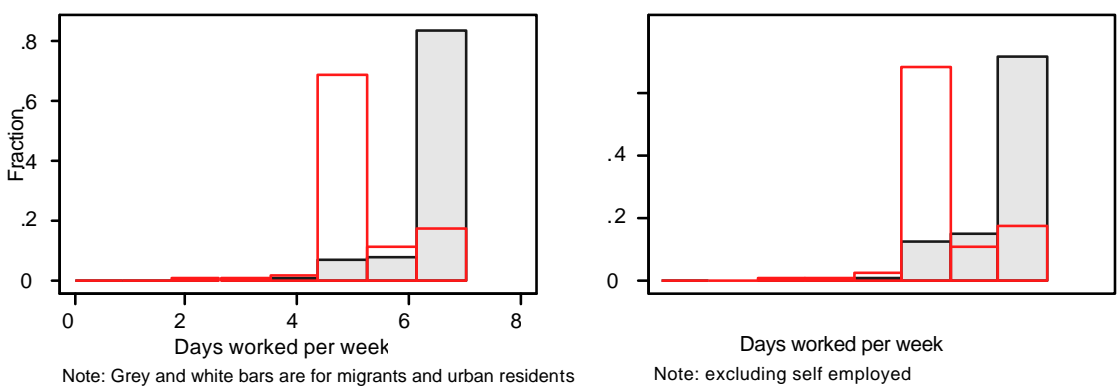

where $H_{i u}$ indicates the hours worked for individual $i$ with urban resident status $u$. $W$ is a vector of control variables, including age, age squared, years of schooling, whether the individual is self-employed, the proportion of household members aged five and below, and provincial dummy variables controlling for regional variation in hours worked (related to weather, or culture).

Health is a dummy variable generated from a self-assessed health question. In the survey, each individual was asked to rate their health relative to individuals of their own age, ranging from one, indicating very healthy, to five, very ill. The dummy variable for unhealthy is set equal to one if an individual self-rated as ill (four) or very ill (five). Note that there might be a relationship between current health and past hours worked, but in Equation 1, we are interested in the relationship between current health and current hours worked, and our analysis should not suffer from the problem of reverse causality. Thus, we believe that Health in Equation 1 is an exogenous variable.

Equation (1) is estimated using a tobit model for urban residents aged 16-65 and for male and female samples separately. The results are presented in Table 
10.4. Age has an inverse U-shape effect on hours worked: more-educated people work more, self-employed work extremely long hours, individuals with bad health work less, and people in large cities (Beijing in the case of the CIDS and Shanghai in the case of the CULS) work longer hours (the results on regional dummy variables are omitted from Table 10.4).

The presence of young children, however, does not seem to have a consistent effect over the two surveys. In the case of the CIDS, having young children increases male and female working hours, though the effect is marginally significant for females. In the case of the CULS, the effect is negative for males and females but not statistically significant for men. The reason for such a difference is not entirely clear. Perhaps, in large cities (CULS), where income levels are high, women can afford to quit jobs when they have young children. This might not be the case in medium and small cities (CIDS).

The results presented in Table 10.4 are then used to predict migrant hours worked

$$
H_{i m t}=W 2_{i m t} \beta_{u}+\delta_{u} H_{e a l t h}
$$

Figure 10.3 shows the distribution of actual hours, $H_{i m t}$ and predicted hours, $H_{\text {ime }}{ }^{11}$

We find that had migrants behaved like urban residents, they would have worked about 50-100 per cent less hours on average than what they actually did (see also Table 10.5). The results are consistent across the two survey samples. ${ }^{12}$

\section{What has been the impact of these long hours on migrant poverty?}

This question is examined by first estimating the following household income per capita equation for the migrant sample

$$
\ln Y_{j m t}=X 2_{j m t} \beta+\delta H_{j m t}+e_{j m t}
$$

where $Y_{j m}$ is annual per capita income for migrant $(m)$ household $j, X$ is a vector of exogenous variables including age and age squared of the household head, years of schooling of the household head and his/her spouse, the gender of the household head, the proportion of the household members who are children (aged below 16), young adults (aged 16-20) and elderly (aged above 65), household size and regional dummy variables. $H$ is hours worked per capita (total hours worked by all household 
Table 10.4 Selected results from tobit estimation of hours worked for urban residents and real and predicted hours for migrants

\begin{tabular}{|c|c|c|c|c|}
\hline & \multicolumn{2}{|c|}{ CIDS, 2002} & \multicolumn{2}{|c|}{ CULS, 2001} \\
\hline & Males & Females & Males & Females \\
\hline \multicolumn{5}{|c|}{ Hours worked, urban residents } \\
\hline Constant & $\begin{array}{r}-675.55 \\
(15.17)\end{array}$ & $\begin{array}{c}-883.45 \\
(22.73)\end{array}$ & $\begin{array}{r}-327.36 \\
(30.26)\end{array}$ & $\begin{array}{c}-336.78 * \cdots \\
(41.18)\end{array}$ \\
\hline \multirow[t]{2}{*}{ Age } & $41.63^{\prime *}$ & $50.47^{\prime+1}$ & $23.11^{\prime \prime \prime}$ & $18.25^{\prime \prime \prime}$ \\
\hline & $(0.71)$ & $(1.11)$ & $(1.39)$ & $(1.90)$ \\
\hline \multirow[t]{2}{*}{$\mathrm{Age}^{2}$} & $-0.51^{\prime+\ldots}$ & $-0.67^{\prime}$ & $-0.31^{\prime \prime \prime}$ & $-0.29^{\prime+*}$ \\
\hline & $(0.01)$ & $(0.01)$ & $(0.02)$ & $(0.02)$ \\
\hline Years of schooling & $\begin{array}{c}2.39 \\
(0.41)\end{array}$ & $\begin{array}{l}10.17^{*+1} \\
(0.58)\end{array}$ & $\begin{array}{l}5.86 \\
(0.74)\end{array}$ & $\begin{array}{l}15.95^{*} \\
(1.10)\end{array}$ \\
\hline \multicolumn{5}{|l|}{ Proportion of household } \\
\hline members aged $0-5$ & $\begin{array}{c}91.07^{+} \\
(15.17)\end{array}$ & $\begin{array}{c}36.55^{*} \\
(19.93)\end{array}$ & $\begin{array}{l}-36.05 \\
(30.82)\end{array}$ & $\begin{array}{c}-179.88^{*+*} \\
(38.814)\end{array}$ \\
\hline \multicolumn{5}{|l|}{ Dummy for } \\
\hline self-employed & $\begin{array}{r}101.90 \\
(6.03)\end{array}$ & $\begin{array}{c}154.32 \\
(8.88)\end{array}$ & $\begin{array}{c}154.88 \\
(7.68)\end{array}$ & $\begin{array}{l}262.07 \\
(11.377)\end{array}$ \\
\hline \multirow[t]{2}{*}{ Dummy for bad health } & $-57.74^{\prime+*}$ & $-36.08^{*+*}$ & $-68.66^{*+*}$ & $-60.98^{*+*}$ \\
\hline & $(6.31)$ & $(7.58)$ & $(8.08)$ & $(9.68)$ \\
\hline \multicolumn{5}{|l|}{ Regional effect } \\
\hline $\begin{array}{l}\text { Number of } \\
\text { observations }\end{array}$ & 7,836 & 8,144 & 3,181 & 3,459 \\
\hline Pseudo $\mathrm{R}^{2}$ & 0.06 & 0.06 & 0.04 & 0.06 \\
\hline
\end{tabular}

Table 10.5 Real and predicted work hours for rural migrants

\begin{tabular}{lcccc}
\hline & \multicolumn{2}{c}{ CIDS, 2002 } & \multicolumn{2}{c}{ CULS, 2001 } \\
& Mean & Median & Mean & Median \\
Real hours worked & 278 & 294 & 285 & 301 \\
Predicted hours worked & 186 & 188 & 171 & 152 \\
(Real/Predicted)-1 & 49.46 & 56.38 & 66.67 & 98.03 \\
\hline
\end{tabular}


Figure 10.3 Real and predicted hours worked per month

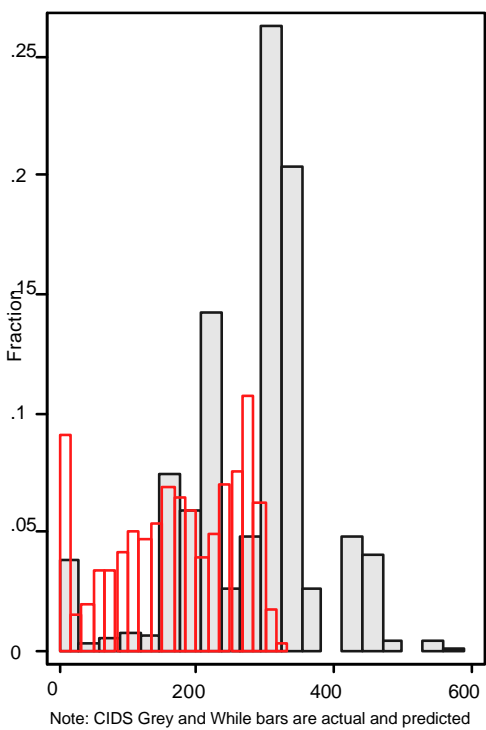

Note: CIDS Grey and While bars are actual and predicted hours, respectively
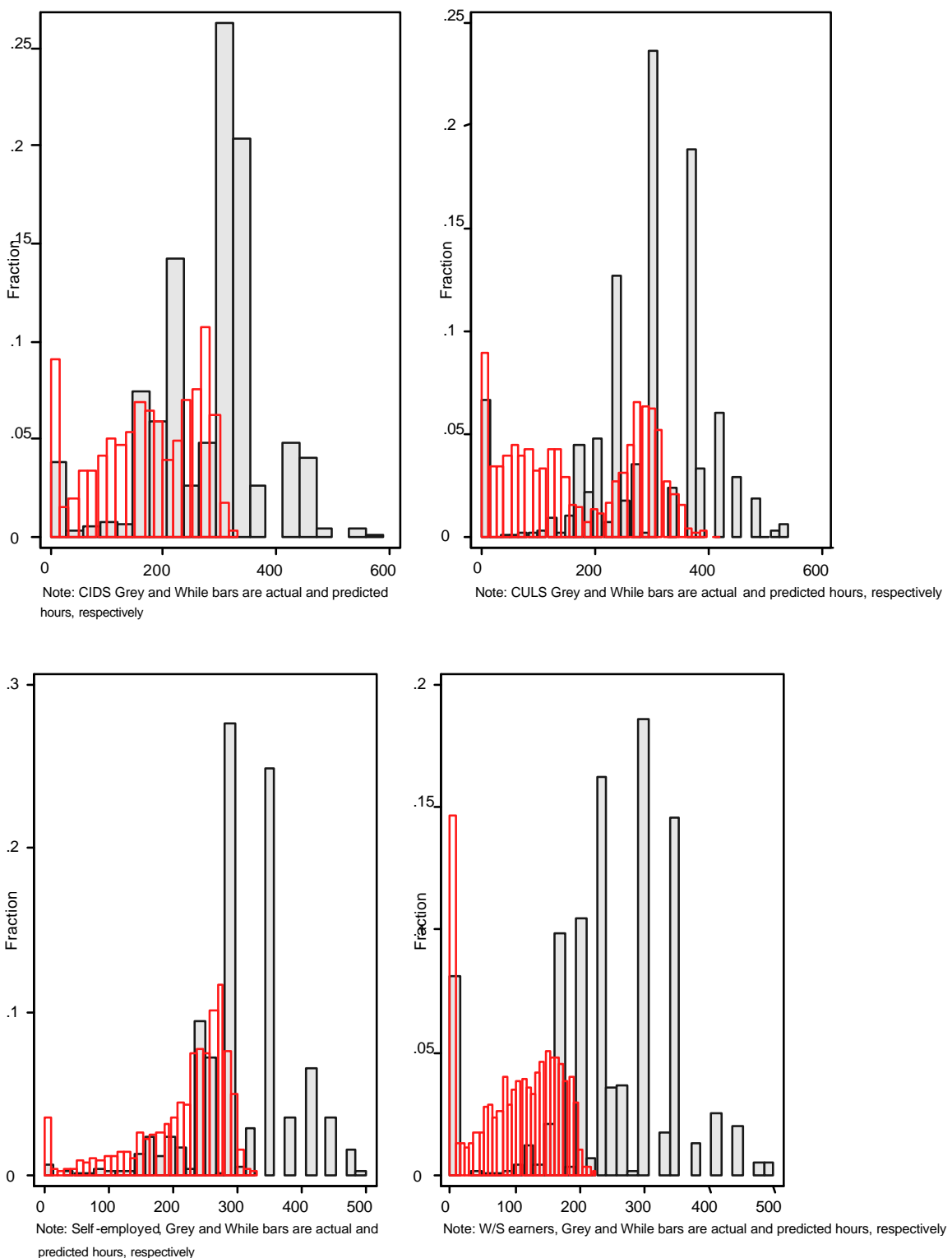
members divided by the total number of household members). Note that hours worked, $H$, might be endogenous in Equation 3 as household per capita income might affect per capita working hours.

We use the number of household members stated as being currently unhealthy as the instrument to handle this possible endogeneity problem. We argue that it is unlikely that an individual's current health should affect current income through channels other than hours worked. Thus, the exclusion restriction should be satisfied.

After fitting Equation 3, we calculate the predicted income level of migrant households as

$$
\ln Y_{j m t}^{H i m t}=X 2_{j m t} \beta+\delta H_{j m t}+e_{j m t}
$$

assuming that the household members had worked like urban residents, $H_{j m t}{ }^{13}$ Based on this predicted income level, we reassess the poverty rate of our migrant sample.

The results of estimated Equation 3 using OLS and IV-GMM for the CIDS total and wage and salary earner samples are reported in Table 10.6. They are largely consistent across the two estimations. In general, the age of the household head has an inverse U-shape relationship with per capita household income, although it is statistically significant only in the case of OLS estimation. The effect of years of schooling of the household head is strong and positive for both estimations, while spouse years of schooling is not statistically significant in the total sample for the IV estimate but is significant in any other cases.

Households headed by males seem to earn less in the case of the total sample, but this is not true for the sample of wage and salary earners, where the coefficients are positive, although only in the case of IV estimates is it statistically significant. The marital status of the household head does not seem to affect household per capita income, except for the IV estimate using the sample of wage and salary earners, where a negative and significant effect is found.

The proportion of household members who are children (aged 0-15) contributes negatively and significantly to household per capita income levels, so does household size, while the proportion of teenagers and old people have no statistically significant effect.

Turning to the most important variable of our estimation, household per capita monthly hours worked, we find that this has a positive and statistically significant effect on household per capita income. The effect is larger while using the IV- 


\section{Table 10.6 Selected results from per capita household income equation}

\begin{tabular}{|c|c|c|c|c|c|}
\hline & \multicolumn{2}{|c|}{ CIDS, total sample } & \multicolumn{3}{|c|}{ CIDS, wage and salary earners } \\
\hline & OLS & IV-GMM & OLS & IV-GMM & \\
\hline Constant & $\begin{array}{l}7.462 \\
(0.309)^{\star \star \star}\end{array}$ & $\begin{array}{c}3.034 \\
(2.310)\end{array}$ & $\begin{array}{l}7.495 \\
(0.381)^{\star \star \star}\end{array}$ & $\begin{array}{c}3.127 \\
(2.429)\end{array}$ & \\
\hline \multicolumn{6}{|l|}{ Per capita } \\
\hline hours worked & $\begin{array}{l}0.119 \\
(0.032)^{\star \star \star}\end{array}$ & $\begin{array}{c}0.933 \\
(0.424)^{\star *}\end{array}$ & $\begin{array}{c}0.168 \\
(0.040)^{\star \star \star}\end{array}$ & $\begin{array}{c}0.925 \\
(0.419)^{\star *}\end{array}$ & \\
\hline Household head age & $\begin{array}{l}0.046 \\
(0.012)^{\star \star \star}\end{array}$ & $\begin{array}{c}0.028 \\
(0.016)^{*}\end{array}$ & $\begin{array}{c}0.026 \\
(0.014)^{*}\end{array}$ & $\begin{array}{c}0.018 \\
(0.017)\end{array}$ & \\
\hline \multicolumn{6}{|l|}{ Household } \\
\hline head age ${ }^{2}$ & $\begin{array}{l}-0.001 \\
(0.000)^{\star * *}\end{array}$ & $\begin{array}{l}-0.000 \\
(0.000)\end{array}$ & $\begin{array}{l}-0.000 \\
(0.000)^{\star *}\end{array}$ & $\begin{array}{l}-0.000 \\
(0.000)\end{array}$ & \\
\hline \multicolumn{6}{|l|}{ Household head } \\
\hline gender, male $=1$ & $\begin{array}{l}-0.07 \\
(0.037)^{*}\end{array}$ & $\begin{array}{c}0.015 \\
(0.058)\end{array}$ & $\begin{array}{c}0.091 \\
(0.049)^{*}\end{array}$ & $\begin{array}{l}0.217 \\
(0.083)^{\star * \star}\end{array}$ & \\
\hline \multicolumn{6}{|l|}{ Household head } \\
\hline years of schooling & $\begin{array}{l}0.031 \\
(0.006)^{\star \star \star}\end{array}$ & $\begin{array}{l}0.036 \\
(0.007)^{\star \star \star}\end{array}$ & $\begin{array}{l}0.026 \\
(0.007)^{\star \star \star}\end{array}$ & $\begin{array}{l}0.029 \\
(0.009)^{\star \star \star}\end{array}$ & \\
\hline \multicolumn{6}{|l|}{ Spouse years } \\
\hline of schooling & $\begin{array}{c}0.007 \\
(0.005)\end{array}$ & $\begin{array}{c}0.006 \\
(0.005)\end{array}$ & $\begin{array}{c}0.015 \\
(0.006)^{\star *}\end{array}$ & $\begin{array}{l}0.023 \\
(0.009)^{\star * \star}\end{array}$ & \\
\hline \multicolumn{6}{|l|}{ Household head } \\
\hline married & $\begin{array}{c}0.032 \\
(0.082)\end{array}$ & $\begin{array}{l}-0.038 \\
(0.103)\end{array}$ & $\begin{array}{l}-0.099 \\
(0.091)\end{array}$ & $\begin{array}{l}-0.163 \\
(0.116)\end{array}$ & \\
\hline \multicolumn{6}{|l|}{ Percentage of } \\
\hline children aged $0-15$ & $(0.108)^{\star * *}$ & $(0.522)$ & $(0.136)^{\star \star \star}$ & $(0.422)$ & \\
\hline \multicolumn{6}{|c|}{ Percentage of household } \\
\hline aged $16-20$ & $\begin{array}{l}-0.171 \\
(0.106)\end{array}$ & $\begin{array}{l}-0.006 \\
(0.148)\end{array}$ & $\begin{array}{l}-0.083 \\
(0.102)\end{array}$ & $\begin{array}{l}-0.07 \\
(0.116)\end{array}$ & \\
\hline \multicolumn{6}{|c|}{ Percentage of household } \\
\hline aged above 65 & $\begin{array}{l}-0.119 \\
(0.248)\end{array}$ & $\begin{array}{l}-0.292 \\
(0.353)\end{array}$ & $\begin{array}{l}-0.211 \\
(0.236)\end{array}$ & $\begin{array}{l}-0.338 \\
(0.290)\end{array}$ & \\
\hline Household size & $\begin{array}{l}-0.135 \\
(0.022)^{\star \star \star}\end{array}$ & $\begin{array}{l}-0.068 \\
(0.042)\end{array}$ & $\begin{array}{l}-0.186 \\
(0.028)^{\star \star \star}\end{array}$ & $\begin{array}{l}-0.092 \\
(0.060)\end{array}$ & \\
\hline Region & Yes & Yes & Yes & Yes & \\
\hline \multicolumn{2}{|c|}{ Number of observations } & 1,804 & 1,804 & 826 & 826 \\
\hline Adjusted $\mathrm{R}^{2}$ & 0.23 & & 0.33 & & \\
\hline \multicolumn{3}{|c|}{$F$ tests for the strength of the instrument } & 19.49 & & 22.78 \\
\hline
\end{tabular}

Notes: Standard errors in parentheses. ${ }^{*}$ significant at 10 per cent. ${ }^{* *}$ significant at 5 per cent. *** significant at 1 per cent

Source: Chinese Academy of Social Sciences, 2002. China Income Distribution Survey (CIDS), Institute of Economics, Chinese Academy of Social Sciences. 
Figure 10.4 Real and predicted per capita income
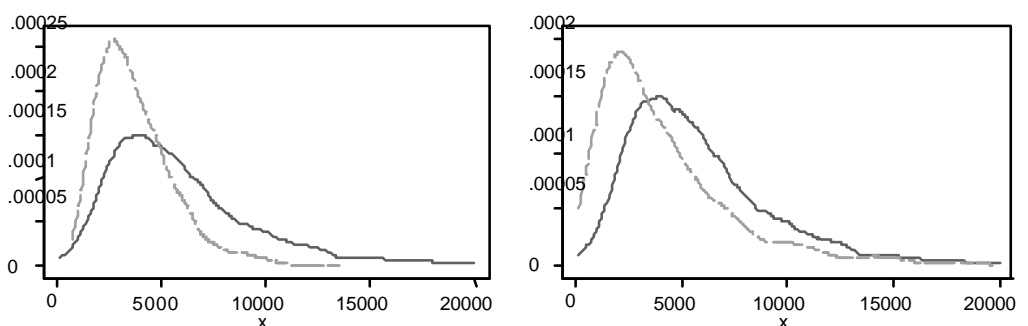

Not including residual, total sample

Solid and dotted lines are actual and pred pc/inc incl. resid, total sample


Note: CULS Solid and dotted lines are actual and predicted pc/inı

Note: CULS Solid and dotted lines are actual and predicted pc/inc incl. resid

GMM estimate. ${ }^{14}$ Using the IV estimate, the coefficient indicates that every additional household per capita hour worked per month increases household per capita annual income by 0.8 and 0.7 per cent for the total and wage/salary earner samples, respectively. Thus, if migrants work 100 hours less per month, which is about the difference in real and predicted hours worked for migrants (see Table 10.5), their per capita annual income would reduce by 50 per cent.

The distribution of the predicted and real incomes is presented in Figure 10.4. The top panel of this figure are graphs with and without including the residual term from the CIDS total sample, while the bottom panel presents the same graphs from the wage and salary earner sample. It is quite clear from these figures that the distribution of migrant per capita household income would have shifted to the left significantly. The mean and median income reduced by about 33-49 per cent (see Table 10.7).

Finally, in the bottom panel of Table 10.7, we present the real and predicted poverty headcount indices and poverty gaps. Not surprisingly, with predicted income, the poverty headcount index increased from 16 per cent to 41 per cent in the CIDS total sample, and from 20 per cent to 56 per cent in the sub-sample of 


\section{Table 10.7 Real and predicted per capita income and poverty rates}

\begin{tabular}{|c|c|c|c|c|}
\hline & \multicolumn{2}{|c|}{ CIDS, total sample } & \multicolumn{2}{|c|}{ CIDS, wage and salary earners } \\
\hline & Mean & Median & Mean & Median \\
\hline \multicolumn{5}{|l|}{ Real per capita } \\
\hline household income (R1) & 6,486 & 5,200 & 5,495 & 4,863 \\
\hline \multicolumn{5}{|l|}{$\begin{array}{l}\text { Predicted per capita } \\
\text { household income }\end{array}$} \\
\hline (no residual) (R2) & 4,496 & 4,192 & 3,552 & 3,315 \\
\hline \multicolumn{5}{|l|}{$\begin{array}{l}\text { Predicted per capita } \\
\text { household income }\end{array}$} \\
\hline (including residual) (R3) & 5,747 & 4,131 & 4,253 & 3,295 \\
\hline$(\mathrm{R} 1) /(\mathrm{R} 3)-1$ & 12.86 & 25.88 & 29.20 & 47.59 \\
\hline & Poverty rate & Poverty gap & Poverty rate & Poverty gap \\
\hline Real income & 0.15 & 0.13 & 0.20 & 0.11 \\
\hline $\begin{array}{l}\text { Predicted income } \\
\text { (no residual) }\end{array}$ & 0.16 & 0.07 & 0.35 & 0.1 \\
\hline $\begin{array}{l}\text { Predicted income } \\
\text { (including residual) }\end{array}$ & 0.28 & 0.19 & 0.41 & 0.19 \\
\hline
\end{tabular}

Source: Chinese Academy of Social Sciences, 2002. China Income Distribution Survey (CIDS), Institute of Economics, Chinese Academy of Social Sciences.

wage and salary earners, an increase of 25-36 percentage points. Poverty severity also increased in both cases.

The above analyses suggest that below-average hourly income for migrants, relative to urban residents, is offset largely by above-average hours worked. In this way, migrant poverty as typically measured is considerably reduced. Once the difference in hours worked between migrants and urban residents is taken into account, we find that migrants would have suffered considerably more from poverty had they worked the same hours as their urban counterparts. Our findings raise many questions as to the relationships between poverty measures, hourly income and total work hours that have not received much attention in the poverty literature.

\section{The health impact of long work hours}

Guest workers come with very clear short-term objectives: earn and save as much money as possible in the limited time they have in the cities. As a result, they work extremely long hours. Such long working hours clearly have pushed many of them to earn an income that is above the poverty line-but at what cost? Perhaps the long working hours have long-term adverse impacts on their health. If we believe in 
Goodman's (1972) model, where health is regarded as part of human capital, extremely long work hours might reduce healthy human capital and future earnings.

To analyse this issue, we need information on current health, Health ${ }_{t}$ and previous hours worked, $H_{t-n}$, for rural migrants to eliminate the possible problem of hours worked being an endogenous variable. Fortunately, the CULS collected hours worked at the beginning of the current job, if the individual was working, and at the beginning of the last job, if the individual was not currently working. There is, however, a problem. Under the guest-worker system, migrants who are unhealthy are more likely to go back to their home villages because they have no access to health insurance, ${ }^{15}$ unemployment benefits or a basic safety net in the cities. This is likely to generate a selection bias and make the observed relationship between hours worked previously and current health not meaningful.

To resolve this problem, we estimate the previous work-hours-health relationship for urban residents and assume that on average migrants: 1) have a similar level of inherited health; 2) have a similar level of nutrition intake; 3) have a similar level of access to a similar quality of health care; and 4) the type of jobs they take have similar effects on their health stock as their urban counterparts.

Under these assumptions, we can predict health conditions for rural residents as a result of their long working hours using estimated results for the urban sample. We acknowledge that these are strong assumptions, however, we believe that the direction of the violation of these assumptions is more likely to bias our predictions downwards. For example, migrants are more likely to have worse nutrition intake, and less access to good health care, and the type of jobs they take might have more adverse effects on health than jobs taken by urban residents.

The first assumption, however, is difficult to judge. Assuming urban and rural people have the same distribution of genetic health, it is not clear whether those with better or worse genes are more likely to migrate. If we assume the former, the violation of this assumption might bias our result upwards, but this upward bias might be offset by the violation of the other three assumptions.

The health equation might be written as follows

$$
\text { Health } h_{i t}=W 2_{i t} \beta+\delta H_{i t-n}+\hat{l}_{i t}
$$

where $\mathrm{Health}_{i t}$ is individual is self-assessed health measure. To estimate Equation 5 , we use two health measures: one is from the question, 'Relative to last year, is your health worse?', and the second is from the question, 'Relative to your own age group, how do you rate your health?'. 
As presented before, we create a dummy variable indicating ill or very ill. Wis a vector of exogenous variables that might affect the individual's health, including age, years of schooling (knowledge of health care and proxy for income), height (proxy for genetic health), whether an individual has a disability, whether an individual is working and how long the individual has been working in the current/previous job. $H_{t-n}$ is hours worked at the beginning of the current job if the individual is working and at the beginning of the last job if the individual is not working.

To estimate Equation 5, there are three issues that need particular attention. First, hours worked at the beginning of the current/last job might not adequately measure the hours worked since the beginning of the job. If this is the case, our main variable, $H_{t-n}$ might not capture our point of interest, which is the impact of continued long working hours on health.

To test whether hours worked in a job have continuity, we correlated the hours worked at the beginning and the end of the current/last job and the correlation coefficient was 0.95 , suggesting a consistency in hours worked for the duration of a job. Second, the timing of the beginning of the current/last job differs significantly among different individuals. Some people started a job 20 years ago, and others started one year ago. To capture this variation, we include a variable 'How long has the individual been working in the current/last job?'. In addition, we restrict our sample to a certain starting year. ${ }^{16}$ Third, age is a very important health factor. As the age distribution of urban residents differs considerably from that of migrants (see Figure 10.5) — migrants are much younger-we restrict our sample to those who were younger than 51 years of age at the time of the survey.

Equation (5) is estimated using a probit model and the results are presented in Table 10.8. The left and right panels present results for whether an individual's health is worse relative to the previous year, and whether an individual is unhealthy relative to individuals of their own age. For the first dependent variable, the only statistically significant independent variables are age and hours worked at the beginning of the current/last job. That is, older individuals are more likely to think that their health is deteriorating, and the more hours worked previously, the more likely that they think their health is worse.

Turning to whether individuals rate themselves as unhealthy relative to individuals of their own age, we find more statistically significant coefficients. Age has a strong positive impact on being worse off than the previous year and being unhealthy relative to an individual's own age group. ${ }^{17}$

There is no effect of gender, education or height on health, and is quite unusual. Perhaps this is due to the sample restrictions. We find that without our restrictions 


\section{Figure 10.5 Age distribution of urban residents and migrants}

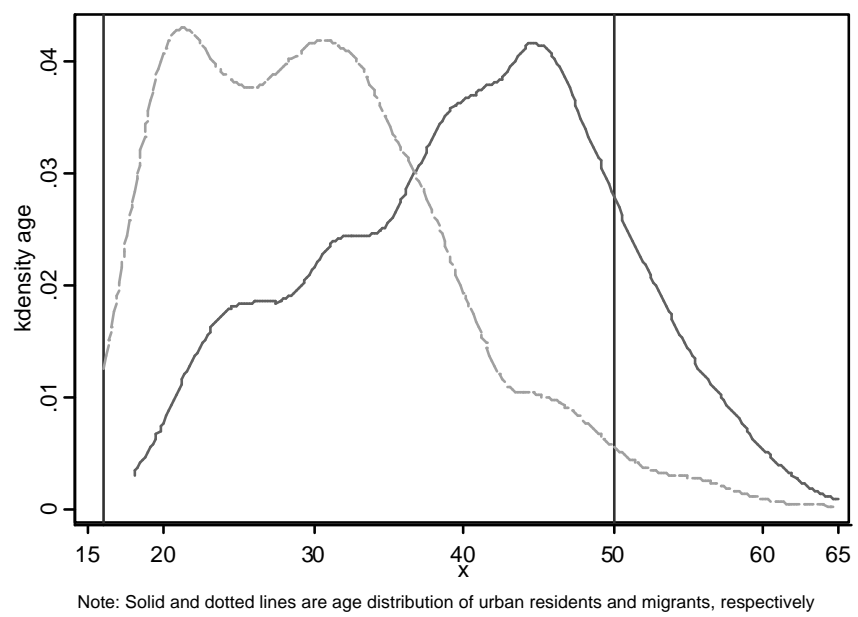

Note: Solid and dotted lines are age distribution of urban residents and migrants, respectively.

on age and hours worked, and excluding the hours worked variable (that is, including people who never worked), age has an inverse U-shape relationship with being unhealthy, and years of schooling and height contribute negatively to being unhealthy.

Whether an individual is currently working has no effect on whether he/she feels worse health-wise, relative to the previous year, but those who are working are significantly less likely to feel unhealthy. While the duration of current/last job has no effect on feeling worse or unhealthy, those who have a disability are more likely to state that they are unhealthy.

Our main variable of interest is 'hours worked at the beginning of the current/ last job'. This variable has a consistent and significantly positive effect on an individual's self-rating as being unhealthy. Every additional hour worked per month increases the probability of feeling unhealthy by 0.02 per cent. The magnitude is smaller for estimations with less restrictions on the earliest starting year of a job, but they are still statistically significant at the 10 per cent level.

Using these estimated marginal effects, we then predict the effect of the extremely long hours worked by migrants on their health. The results are presented in Table 10.9. The first and second rows present the proportion of people who 
The impact of the guest-worker system

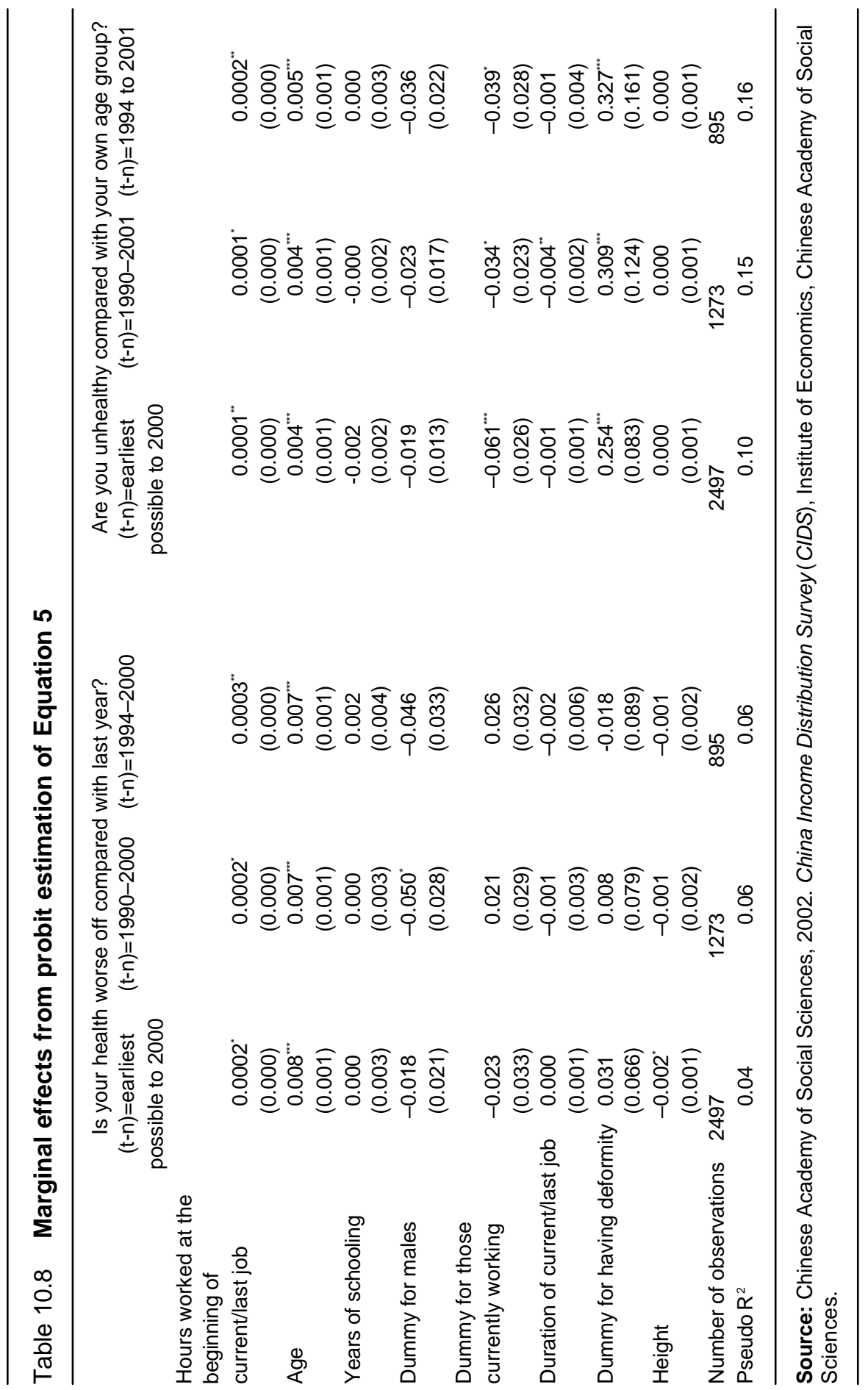


The Turning Point in China's Economic Development

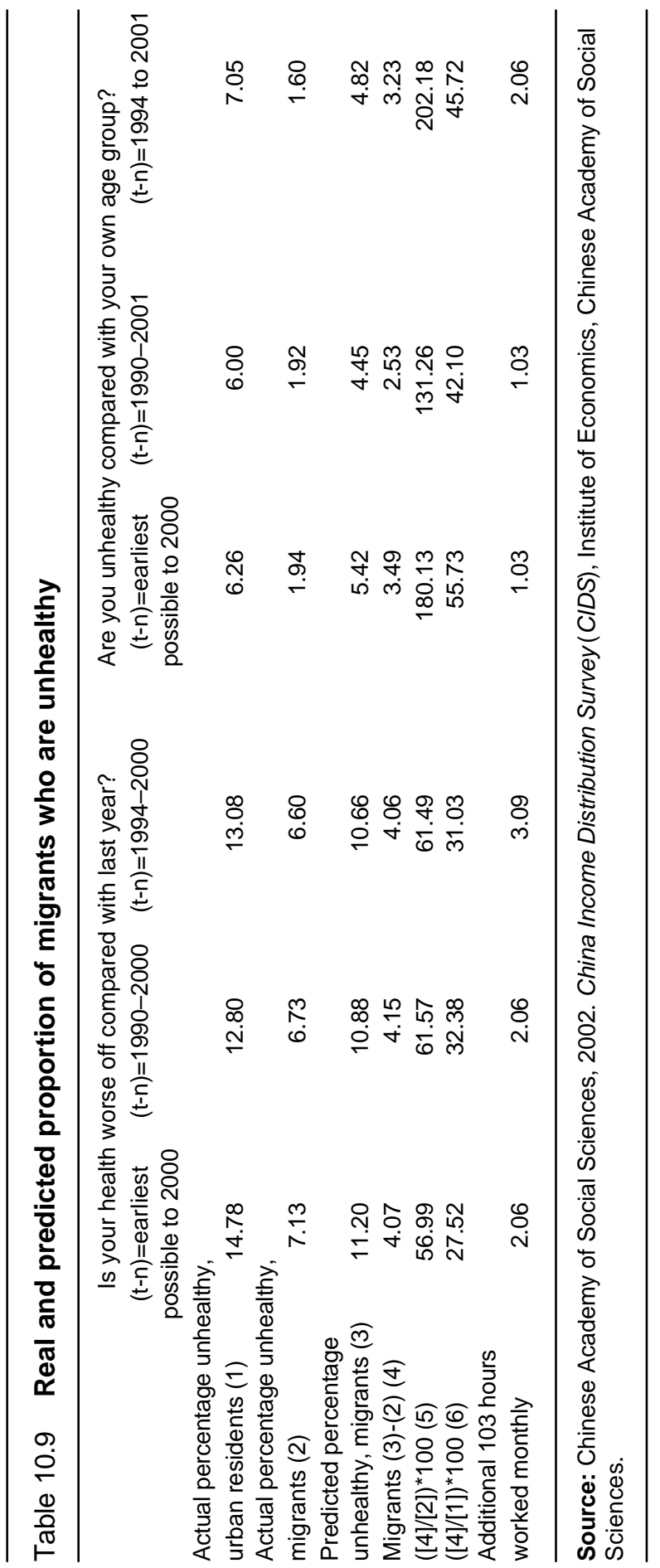


stated that their health was worse than the previous year or that they were unhealthy compared with their own age group, for urban residents and migrants, respectively.

The proportion of urban residents who stated that their health was worse than the previous year was more than double that of migrants, while for those who said they were unhealthy, the difference was more than three times. These differences, perhaps, are due to the selection effect on migrants, as discussed earlier. That is, those who are sick to start with do not come to the city and those who become sick leave.

If we assume that the distribution of genetic health between those who stay in the countryside and those who migrate to cities is similar, the major selection effect should be from those who have left for their rural home due to sickness developed in the city.

The third row uses the estimated coefficients from the urban equation to predict what would have been the proportion of migrants whose health was worse than the previous year, or who were unhealthy, had they had the same genetic health distribution, same nutrition intake, same health care and same occupation distribution as urban residents. The fourth row indicates the difference between the real and predicted proportions.

For the sample of migrants who started the current/last job no earlier than 1995 (third column of each panel in Table 10.9), the difference between the predicted and real proportions of those who stated that their health was worse than the previous year is 4.1 percentage points, and the difference between the predicted and real proportions of those who thought that they were unhealthy is 3.23 percentage points. These numbers are 61 and 202 per cent larger than the real occurrences for migrant workers, suggesting, perhaps, that the majority of those who are not healthy have gone home. This is the upper boundary of the proportion of people who are sick and have gone home. Relative to urban residents, these are 31 and 46 per cent of their urban resident real occurrences. This gives the lower boundary of the measure of the proportion of people who are sick and have gone home. ${ }^{18}$

Another way to predict the effect of long working hours on health is to use the average additional monthly hours worked by migrants times the marginal effect of the monthly hours worked on the probability of being worse off health-wise or being unhealthy. On average, migrants in the CULS sample worked 103 hours more per month than urban residents. This can translate to 3.1 percentage points more workers feeling worse off and 2.1 percentage points more workers feeling unhealthy, which is an increase of 50 and 130 per cent of the stated health for migrant workers. 


\section{Conclusions}

In this chapter, we have examined poverty and the well-being of migrant workers in urban China. As guest workers, migrants have short-term objectives, which push them to work extremely hard in the cities. We have found that although a simple income assessment results in a low poverty rate, measured in terms of income for migrant workers relative to their urban resident counterparts, this is due mainly to their long working hours. Had they worked the same hours as urban workers, the poverty rate of the migrants would have increased from 15 per cent to 35 per cent.

Our finding that poverty among migrant workers in China is not related to unemployment in the cities is different from migrant poverty in other countries. Unlike migrant groups in other countries, Chinese rural migrants have very high employment rates-presumably because those who lose jobs are pushed back to the countryside by the guest-worker system and those who cannot find jobs are prevented from coming to the cities in the first place.

The extraordinarily long hours worked by guest workers are not usually factored into poverty analyses and focusing on weekly or annual income, as is usual in poverty studies, disguises how low hourly wages are. The large difference in hours worked between urban people and rural migrants raises a host of questions as to how to incorporate hours worked into a poverty analysis adequately. Obviously, a given income generated by 300 hours' work per month produces a lower level of well-being and a higher rate of 'poverty' than the same income produced by 160 hours' work per month.

In addition, in most poverty studies, a move from an income to an expenditure focus reduces the incidence of poverty, as in most countries the poor spend more than they earn. This is not true in China. Poor rural migrants have high saving rates and, indeed, save proportionately more than their city counterparts. If we examine poverty measured in terms of expenditure, the migrant poverty rate is as high as 32 per cent.

The tension between poverty as usually measured in income and a high savings rate by the 'poor' has a number of important implications. For example, the high savings rate suggests that some of the indicators of current poverty-poor housing in the city and low health expenditure-are partly the result of the decision to save as much as possible while in the city. The high savings rate also raises complex inter-temporal issues about enduring lower living standards now in order to enjoy higher living standards in the future. 
Our study also raises important questions regarding the Chinese guest-worker system. It appears that the system acts as a buffer to reduce urban poverty and urban unemployment. Extreme poverty, which is often generated by urban unemployment and the associated development of urban slums, is largely avoided in China as unsuccessful workers are pushed back to villages if they lose their city jobs and those unable to find city jobs are usually prevented from coming to the cities in the first place.

The system can be thought of as one that minimises urban poverty and the social, economic and political tensions in cities. Pushing unsuccessful, unhealthy and poor people back to the villages, however, is not a long-term optimal solution to overall poverty reduction. The guest-worker system reduces the outflow of labour from the villages and thus keeps rural poverty higher than it would otherwise be. It restricts city employment opportunities and prevents migrants from investing in city skills and thus prevents them from building a long-term income base. In addition, one of our important findings is that the long work hours undertaken by guest workers, to increase their short-term income and savings, might damage their future health and hinder their long-term earning capacity.

\section{Notes}

1 We put aside any general equilibrium impact of migrants on the income levels of urban residents.

2 The provinces include Beijing, Shanxi, Liaoning, Jiangsu, Anhui, Henan, Hubei, Guangdong, Chongqing, Sichuan, Yunan and Gansu.

3 The CULS migrant survey does not include separate individual-level surveys for household members other than the respondent. Limited information on other family members is reported by the main respondent.

4 For detailed sampling procedures, see http://www.msu.edu/ gilesj/Protocol.pdf

5 The CULS claims that migrant workers who were registered by their work unit with local police stations were also included in the sample frame. This might be true to some extent but we still feel that the proportion of self-employed is too high.

6 Summary statistics for self-employed and wage and salary earners separately are presented in Appendix table 10.1.

7 According to Xiang 2003, one consultation for a minor health problem, such as a cold, in a big hospital in Beijing might cost RMB500, almost one month's salary for some migrants.

8 Many case studies and newspaper articles have presented facts with regard to migrants refusing to receive treatment for their health problems due to financial difficulties. For example, 14 migrant workers in a suitcase factory in Beijing were sent to a hospital by the local government when they were found to have severe benzene poisoning in 2002. More than 10 , however, checked out soon afterwards due to a lack of money (Xiao 2002). Another example is that the department of external injuries in Guangdong Province People's Hospital receives about 200 migrant workers a year and more than one-third of them cannot pay the bill after treatment. Some hospitals now refuse to receive migrant patients (Cheng and Wen 2002). 
9 The non-food component is obtained by the following procedure: first, we estimate the food share in total expenditure against the total expenditure deflated by the food poverty line and household size. Second, using the estimated coefficients for each province and each year, we calculate the non-food component of the poverty line for each province and each year. For detailed discussion of how the CBN poverty line is derived in this study, see Meng et al. 2005.

10 The sample is based on several stratifications at the regional, provincial, county, city, town and neighbourhood community levels. Households are selected randomly within each chosen neighbourhood community. The UHIES includes only households with urban household registration. Rural migrants to urban cities are not included in the survey. For a detailed description of the survey, see ibid.

11 Note that as the CULS surveyed only migrant household main respondents regarding their working hours, the real and predicted hours worked for migrants for the CULS are for the main respondents only.

12 The main real number of hours worked presented in Table 10.5 is slightly different from that presented in Table 10.1. This is because only those who do not have missing values on all the variables used in Equation 2 are included in Table 10.5.

13 Note that after predicting migrant household per capita income with $H_{j m t}$, we also give each household back its original error term, $e_{j m t}$, from Equation 3.

14 To test the strength of our instrument, the F-test for excluding the instrument from the first stage estimation is presented at the bottom of Table 10.6. We believe that our instrument is strong in both samples.

15 While about 53 per cent of urban residents have public health insurance, less than 2 per cent of migrants have such benefits.

16 Table 10.9 presents results for different restrictions. The first column for each of the two dependent variables shows the results for the sample of individuals who do not restrict the earliest starting year of the current/last job, but who restricted the latest starting year to 2000 , so that everybody has to be in the job for at least one year as the survey was conducted at the end of 2001. The second column presents the results for individuals whose earliest starting year was 1990, while the third column is restricted to individuals whose earliest starting year was 1995 . As a majority of our migrant sample (62 per cent) started the current/ last job between 1995 and 2000, results from the third column might be more relevant (see Appendix figure 10.1 for the distribution of starting year).

17 The effect is linear due to the age restriction. Once the squared term is included, age and age squared become insignificant. Thus, the squared term is excluded.

18 Here we assume that nutrition intake, health care and occupational distribution are all the same for migrants and urban workers and that those rural workers who have bad genetic health did not come to the cities. 


\section{Appendix Table A10.1 Summary statistics for wage/ salary earners and self-employed (CIDS)}

\begin{tabular}{lcccr}
\hline & \multicolumn{2}{c}{ Urban } & \multicolumn{2}{c}{ Migrants } \\
Variables & $\begin{array}{l}\text { Wage/salary } \\
\text { earner }\end{array}$ & Self-employed & $\begin{array}{c}\text { Wage/salary } \\
\text { earner }\end{array}$ & Self-employed \\
Age & 41 & 40 & 34 & 35 \\
$\begin{array}{l}\text { Years of schooling } \\
\text { Individual annual }\end{array}$ & 12 & 10 & 8 & 8 \\
$\begin{array}{l}\text { income } \\
\text { Monthly hours }\end{array}$ & 12,213 & 11,168 & 7,643 & 10,562 \\
$\begin{array}{l}\text { worked } \\
\text { Hourly income }\end{array}$ & 188 & 256 & 265 & 313 \\
$\begin{array}{l}\text { Number of } \\
\text { observations }\end{array}$ & 5.82 & 4.15 & 2.87 & 3.13 \\
\hline
\end{tabular}

Source: Chinese Academy of Social Sciences, 2002. China Income Distribution Survey (CIDS), Institute of Economics, Chinese Academy of Social Sciences. 
Appendix Table A10.2 Dibao and CBN poverty lines by province, 2002

\begin{tabular}{lcccc}
\hline CIDS 2002 & Dibao line (yuan) & Lower line (yuan) & Upper line (yuan) & (Up-DB)/Up \\
Beijing & 3,480 & 3,286 & 4,433 & 0.21 \\
Shanxi & 1,872 & 1,620 & 2,345 & 0.20 \\
Liaoning & 2,460 & 1,861 & 2,523 & 0.02 \\
Jiansu & 2,640 & 2,233 & 2,874 & 0.08 \\
Anhui & 2,028 & 1,933 & 2,502 & 0.19 \\
Henan & 2,160 & 1,809 & 2,663 & 0.19 \\
Hubei & 2,520 & 2,039 & 2,742 & 0.08 \\
Guangdong & 3,600 & 2,925 & 3,790 & 0.05 \\
Sichuan & 2,136 & 1,836 & 2,318 & 0.08 \\
Congqing & 2,220 & 2,318 & 3,019 & 0.26 \\
Yunnan & 2,280 & 2,275 & 2,841 & 0.20 \\
Gansu & 2,064 & 2,095 & 3,012 & 0.31 \\
Simple average & 2,460 & 2,290 & 2,996 & 0.18 \\
Note: Dibao Lines are for the capital city of each province apart from Beijing and Congqing.
\end{tabular}

Source: Chinese Academy of Social Sciences, 2002. China Income Distribution Survey (CIDS), Institute of Economics, Chinese Academy of Social Sciences.

\section{Appendix Figure A10.1 Distribution of starting year for the current job}

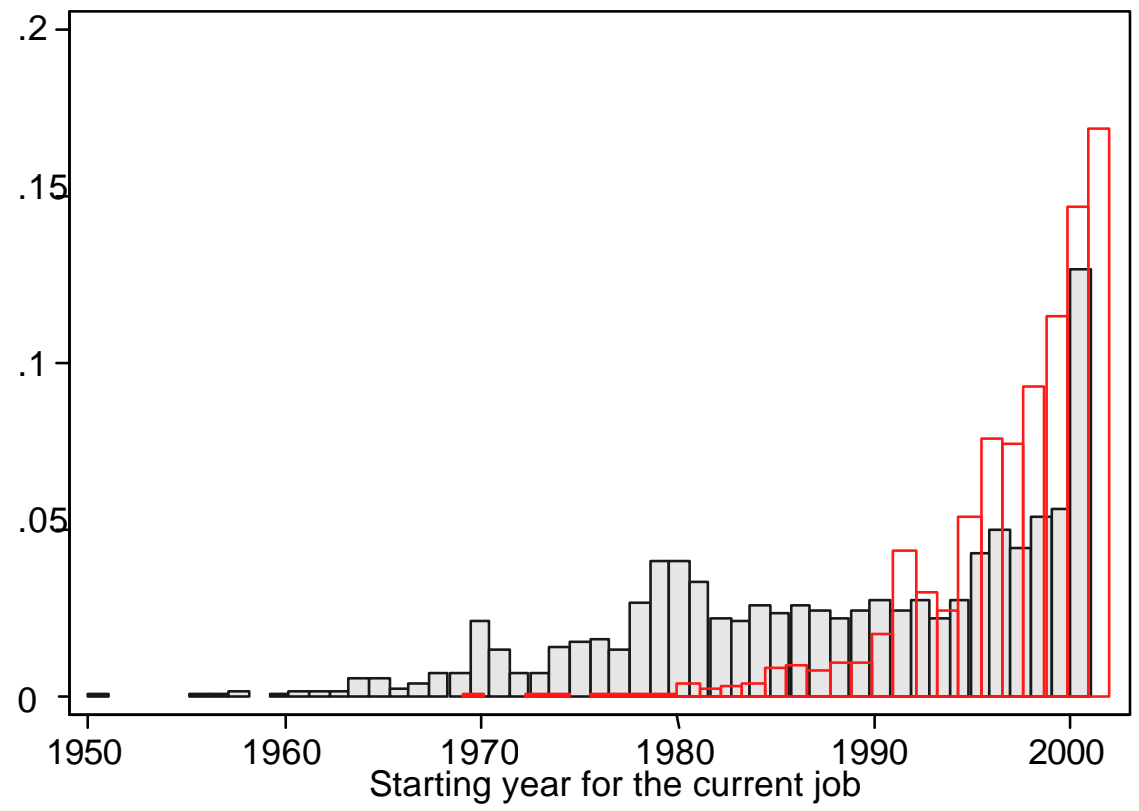

